\title{
No Ordinary Plain: Seeing and Unseeing the Taieri with McCahon
}

\author{
JANE McCABE
}

\begin{abstract}
There are three recorded moments of Colin McCahon encountering the Taieri Plain. In 1936, as a schoolboy, he experienced an epiphany looking over the Taieri from the coastal hills. Six years later, in 1942, he painted Sketch for landscape from Flagstaff, depicting the plain from a northern perspective. In 1966, he famously recalled his early epiphany in an essay entitled "Beginnings." In this essay, I bring a sociohistorical and personal perspective to these three moments, arguing that knowledge of the details that McCahon was seeing and unseeing in his 1942 sketch bring nuance to our understanding of his early development.
\end{abstract}

In the winter of 1942, Colin McCahon stood atop Flagstaff Hill, the high point of the prominent volcanic ridge that dominates the Dunedin city skyline. It is a quick, steep climb, one that is still popular with walkers for the panoramic view it readily reveals, and one that has long been valued as a lookout. Local Māori called the ridge Whaakari, meaning "uplifted to view," and Flagstaff Hill was known as Te Whānaupaki. ${ }^{1}$ Looking to the east, one takes in a magnificent view of Dunedin city, its harbour and peninsula, opening out to the vast southern Pacific Ocean. Pivoting around, the eye moves over the city's western suburbs, and another striking view is revealed - that of the Taieri Plain. Encircled by hills, the flat, intensively farmed plain is framed to the west by the formidable Maungatua ridge, beyond which lies another hinterland.

It was towards this interior that McCahon turned that winter's day, choosing the Taieri Plain and its surrounds as the subject of his painting Sketch for landscape from Flagstaff (1942) [fig. 1]. His turn inwards aligned with a pivotal moment in the young artist's life. Having spent most of his youth in Dunedin, these were the last few months he would live there, prior to marrying Anne Hamblett in September and heading north. ${ }^{2}$ It was also a shift in focus, as his Otago subjects to that point were mostly urban or coastal scenes. ${ }^{3}$ McCahon never painted the Taieri again. He did, however, recall the plain in his oft-quoted "Beginnings" essay in the literary journal Landfall in 1966. In that piece, McCahon famously described a youthful epiphany while looking across the Taieri from a different vantage point - the coastal hills south of Dunedin—six years before his Flagstaff sketch. 


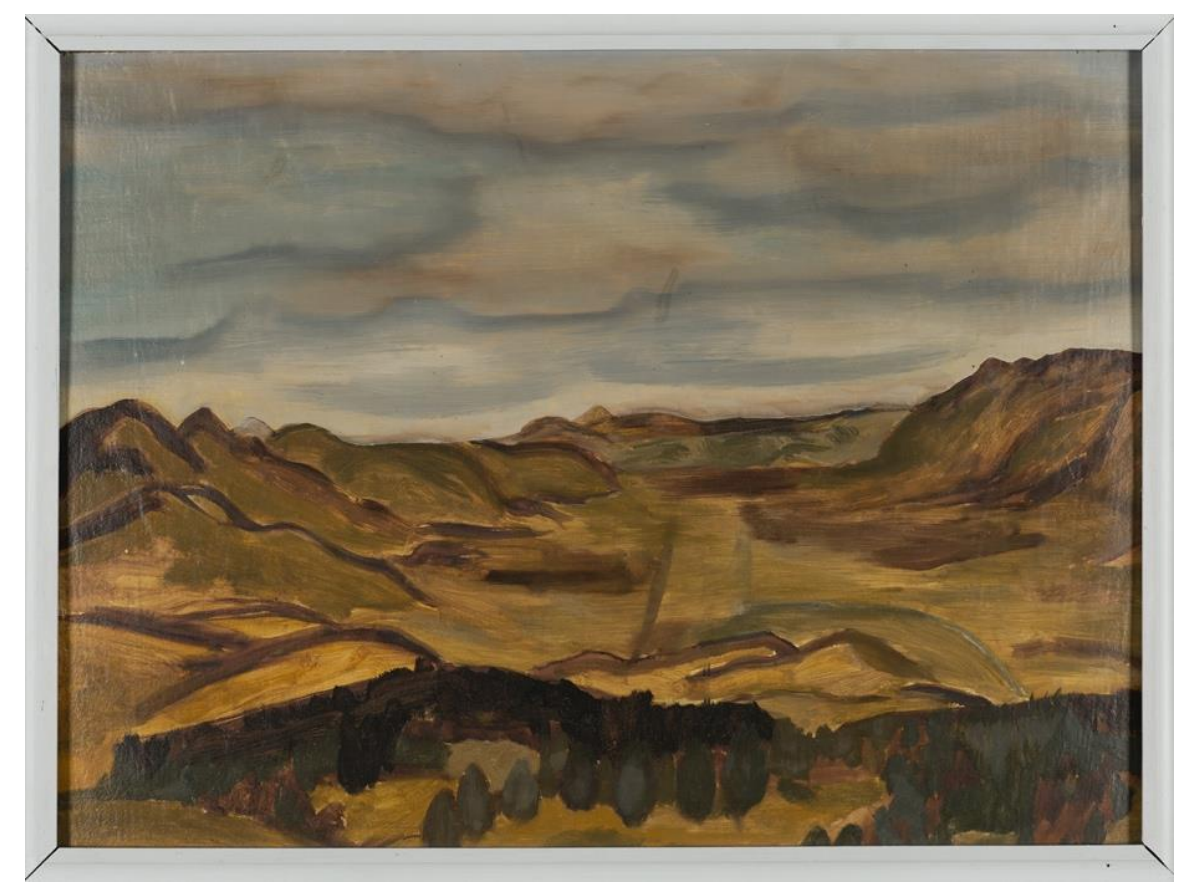

Figure 1. Colin McCahon, Sketch for landscape from Flagstaff, 1942. Oil on gesso on board, $443 \times$ $605 \mathrm{~mm}$. Hocken Collections, Uare Taoka o Hākena, University of Otago, 73/82, John and Ethel

McCahon bequest, 1973 (courtesy of the Colin McCahon Research and Publication Trust).

In this article I consider "McCahon's Taieri" through these three moments of recorded encounter: his vision in 1936, his 1942 painting, and recalling and describing his vision in 1966. No previous writing on McCahon has considered his relationship to the Taieri, nor analysed his Sketch for landscape from Flagstaff. This is understandable, given that only one, very early, work exists with the Taieri as its subject. Yet as the location of his epiphany it carries significance, and, as I argue here, a close examination of the place and his views of itwhich moved from an idealised vision of the grand architecture of the land as a 17-year-old, to a rendering six years later that imparts the life experience he had gained since-brings further nuance to his development prior to the emergence of his first mature works, usually dated to the late 1940s. ${ }^{4}$ In Sketch for landscape from Flagstaff, I suggest, we can see signs of his later ability to make space for multiple, overlapping stories to be read into a landscape.

I approach this topic as a social historian interested in rural attachment to land; as a Pākehā woman and long-time appreciator of McCahon's landscapes; and as a former local of decidedly working-class origins. I grew up in Mosgiel, the town at the centre of the Taieri Plain, and have recently conducted a major research project on the history of rural land inheritance, focusing on two contrasting districts: Taieri, in the lower South Island, and Hokianga in the Far North. ${ }^{5}$ Analysing inheritance practice in rural families of diverse cultural backgrounds, I propose, has the potential to advance our knowledge of the ways in which people attach to land. In light of this aim, I was keen to address artistic interpretations of Taieri and Hokianga, which are of course a direct means of expressing, cultivating and understanding human feeling for place. Knowing that Northland was a significant subject for McCahon, I saw an opportunity to build on my personal interest in his work. It was only later that I learned that he had painted the Taieri Plain, and I was surprised to learn that his famous youthful epiphany occurred while looking across what was, for me, a very ordinary place. 
As I hope is clear from this preamble, I am not an art historian, and do not bring any particular visual expertise nor comprehensive knowledge of McCahon's work to my analysis here. My approach moves between the context-driven social historian and the visually-preoccupied art historian, for the purpose of exploring the value of knowing more about what was depicted, and more importantly what was not, in McCahon's landscapes. As has been well-documented by McCahon scholars, and the artist himself, his mature works took a symbolic approach to landscape, using land-seen and land-experienced as vehicles to communicate deep, often spiritual ideas about human existence and belonging. McCahon's landscapes are certainly connected to particular places - his naming of the works makes this clear-but they are not portraits. Instead of seeking to render any detailed and accurate likenesses, they reach towards a universal meaning. It is from a strong appreciation of this central tenet of McCahon's work that I suggest here that a finely grained study of the subject-place-in this case the Taierinevertheless enhances our reading of his landscapes.

This is not a new suggestion, and indeed many recent accounts of McCahon's work have sought to immerse the reader/viewer in "his" places, Justin Paton's evocative McCahon Country being the most comprehensive example. ${ }^{6}$ But what might usually be a sentence or two about a particular locale, I want to expand here into an entire article. I am suggesting that there is benefit in exploring not only the physical characteristics and the feeling of a landscape that we might recognise in McCahon's depictions of a place we know, but also to bring to the surface aspects of its social history and the experience of living there. The risk here is to open myself to dismissive criticism: that because McCahon intentionally swept aside this detail, discussing the omitted social features of the landscapes that he painted is irrelevant to - and at odds withthe aims of his artistic project. But what I want to do here is more than compare the "actual" or locally-perceived landscape to his painting; rather I seek to bring attention to the varying density of human occupation which McCahon's land-subjects required him to "unsee." For unlike the increasingly remote areas depicted in his later works, the Taieri was saturated with evidence of rural intervention and occupation when McCahon saw and painted it.

In the three sections that follow, I argue that a deeper knowledge of the Taieri and its inhabitants is crucial to appreciating the merit of his Sketch for landscape from Flagstaff. It was from a surveyor's vantage point that the elemental features of the district and an associated spiritual understanding were revealed to the young artist in 1936. In 1942 he again took an elevated perspective, but from a different angle, and created an image of the plain that when read alongside the earliest documented descriptions of walking through it at ground level, communicates his incisive perception of deep aspects of its human occupation-an ability to relate the contours of the land to the affective experience of encountering it, of knowing it. Most notably, his work reveals an aspect of the Taieri that is usually submerged by its apparently settled character: as a "moving through" place, from pre-colonial times to the present. In the final section I reflect on these features in light of McCahon's situation in 1966 when he penned the Landfall essay. I also bring a 2020 perspective to bear, taking McCahon back to the Taieri, showing it to him from new angles, and telling him how remarkable it is that his 1942 work has room for its many histories, and how a former local (that's me) found a kind of peace with her origin place in the process, and that because of all of this, he belongs to the Taieri, as he belonged to all of the places he painted.

\section{Seeing (1936)}

In his commissioned essay "Beginnings" (1966), McCahon famously recalled a vision that he experienced from the perspective of the coastal hills of Otago looking across the Taieri plain: 
Driving one day with the family over the hills from Brighton or Taieri Mouth to the Taieri Plain, I first became aware of my own particular God, perhaps an Egyptian God, but standing far from the sun of Egypt in the Otago cold. Big hills stood in front of little hills, which rose up distantly across the plain from the flat land: there was a landscape of splendour, order and peace. ${ }^{7}$

Building on this dense description, at once simple (big hills and little hills) and weighty (a god inside, or beckoned from a distant land), McCahon wrote of perceiving "something logical, orderly and beautiful, belonging to the land and not yet to its people ... not yet understood or communicated, not really invented." His work since had "largely been to communicate this vision and invent a way to see it." Unsurprisingly, in light of the influential work McCahon had produced in the intervening decades, this sweeping statement of origin and intent has been quoted many times. It is often used as an entry to writing about McCahon's Otago works and his formative experiences in the south, from which he would move onwards, upwardsnorthwards. Yet the Otago landscape, while exhibiting a certain geographical pattern, is remarkably diverse; and the setting and features of the Taieri Plain are highly distinctive. ${ }^{8}$ Here I want to linger on this moment in 1936, before it was a "beginning," and to bring social, historical and geographical detail to the meeting of interior and exterior worlds from which it sprung.

While McCahon did not specify the year of his vision, in his Landfall essay it is nestled between recollections of his time at Otago Boys High and at Dunedin School of Art. Peter Simpson dates it at c.1936, when the artist was 17 years old..$^{9}$ As has been well-documented, McCahon's early life was one of culture and relative comfort, and there is plenty to support this in "Beginnings": his family was a "gallery-going" one; they were educated, literary and outwardlooking. ${ }^{10} \mathrm{He}$ was born in the South Island town of Timaru, but aside from a year in neighbouring Oamaru, McCahon grew up in the city of Dunedin. The family lived in Māori Hill and then Belleknowes, two of the city's most pleasant and affluent suburbs. Both are perched high above the urban centre and afford striking views of the city with its ocean backdrop - similar to the view from Flagstaff, but only in one direction. Viewing the Taieri Plain was only possible by ascending the hills that separated Dunedin from its rural hinterland. 


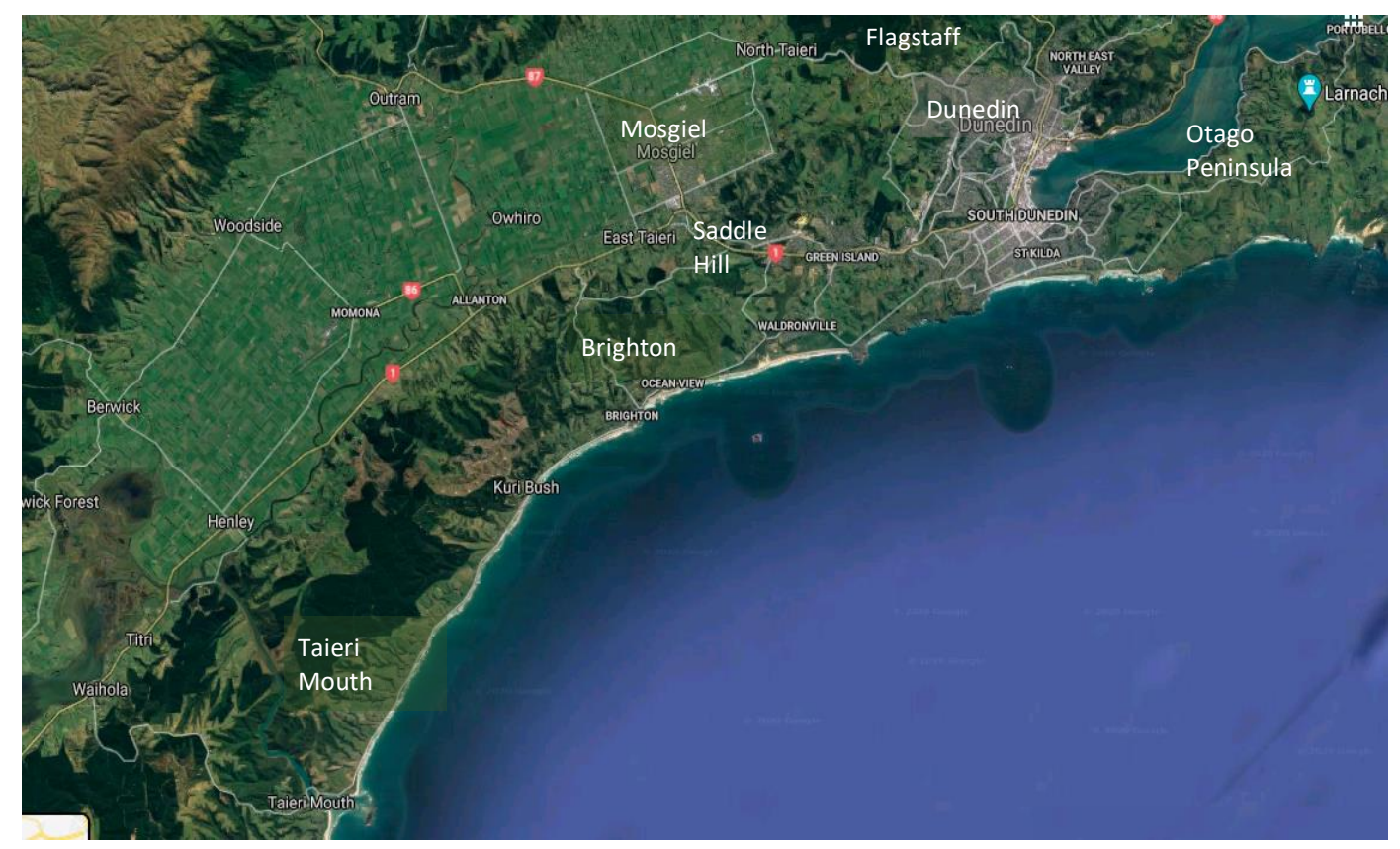

Figure 2. Satellite map showing the large Taieri Plain $30 \mathrm{~km}$ southeast of Dunedin and key sites mentioned in this article: the coastal hills between Brighton and Taieri Mouth where McCahon had his epiphany; Dunedin city, where he grew up; Mosgiel, where the author grew up; Flagstaff, McCahon's angle of vision in 1942; and to the east of Dunedin, the Otago Peninsula, the subject of McCahon's best-known Otago landscapes.

McCahon's description of being out with the family that day calls to mind what was, and still is, a pleasant and very common outing for a Dunedin family - to Brighton beach or Taieri Mouth for a picnic, just a short drive from the city. Writing about McCahon's vision in $A$ History of Otago, Erik Olssen refers to "Baxter's Brighton," noting that the poet James K. Baxter also had a "powerful vision shaped by the Old Testament" in the same location. ${ }^{11}$ McCahon and Baxter were to become close friends and admirers of each other's work, but in 1936 they were still a decade away from meeting. ${ }^{12}$ And while McCahon would go on to paint haunting images that reflected Baxter's influence, his two depictions of Taieri Mouth at this time project the light, cultured, middle-class existence of his youth [figs. 3 and 4]. The first, dated c.1935-37, is a jaunty portrayal of the small Taieri Mouth community - a fishing village that formed along the estuary. Today it is far enough away from Dunedin to attract those who wish to live a life of retreat, and the long stretches of wet sand, shimmering tidal waters and piping sea birds make for a reflective day out. But notably, it is the humanscape that dominates McCahon's drawing. The second, created slightly later, c.1937-39, looks towards Saddle Hill, beyond which lay the Taieri Plain. There are fewer human details, but they are there, nonetheless. 

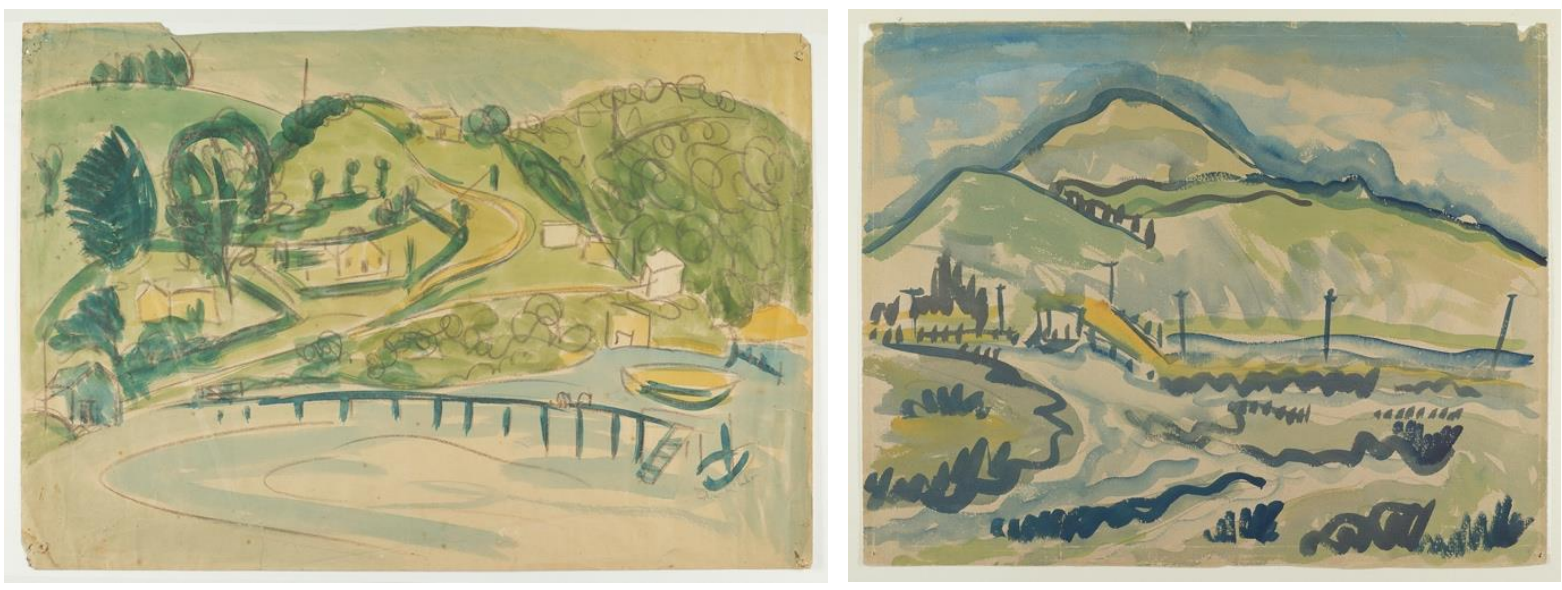

Figure 3 (left). Colin McCahon, Taieri Mouth, c.1936-37. Gouache and brown crayon on paper, $385 \times$ $558 \mathrm{~mm}$. Hocken Collections, Uare Taoka o Hākena, University of Otago, 71/196, given by Colin McCahon, 1971 (courtesy of the Colin McCahon Research and Publication Trust).

Figure 4 (right). Colin McCahon, Saddle Hill [from Taieri Mouth], c.1937-39. Gouache and pencil on buff paper, $405 \times 508 \mathrm{~mm}$. Hocken Collections, Uare Taoka o Hākena, University of Otago, 73/73, John and Ethel McCahon bequest, 1973 (courtesy of the Colin McCahon Research and Publication Trust).

A close look at the satellite map [fig. 2] showing the locales mentioned so far enables the reader to imagine the spectacle of the Taieri coming into view from the hills that surround it. Dunedin city itself is very hilly. Aside from the large flat suburban area in the south of the city, being in Dunedin one either has the feeling of being crowded in by hills or peering down from them into valleys and across urban or ocean vistas. That experience is not limited to the city but also its surrounds: the Otago Peninsula continues this rolling perspective, as do the hills to the north of the city. In contrast, then, is the relatively large flat open plain, dwarfing the city in its extent, but completely hidden from it. The drama of the plain being revealed varies according to the route from Dunedin. The main road used to skirt lower Flagstaff and gradually wind down over Three Mile Hill Road into North Taieri. These days most encounter the plain via the motorway, which zips smoothly over Saddle Hill directly into Mosgiel. This does afford a view of the plain, but it is less striking than McCahon's view from the coastal hills further south, which is one of the most beautiful - and today relatively rare - ways to take in the Taieri.

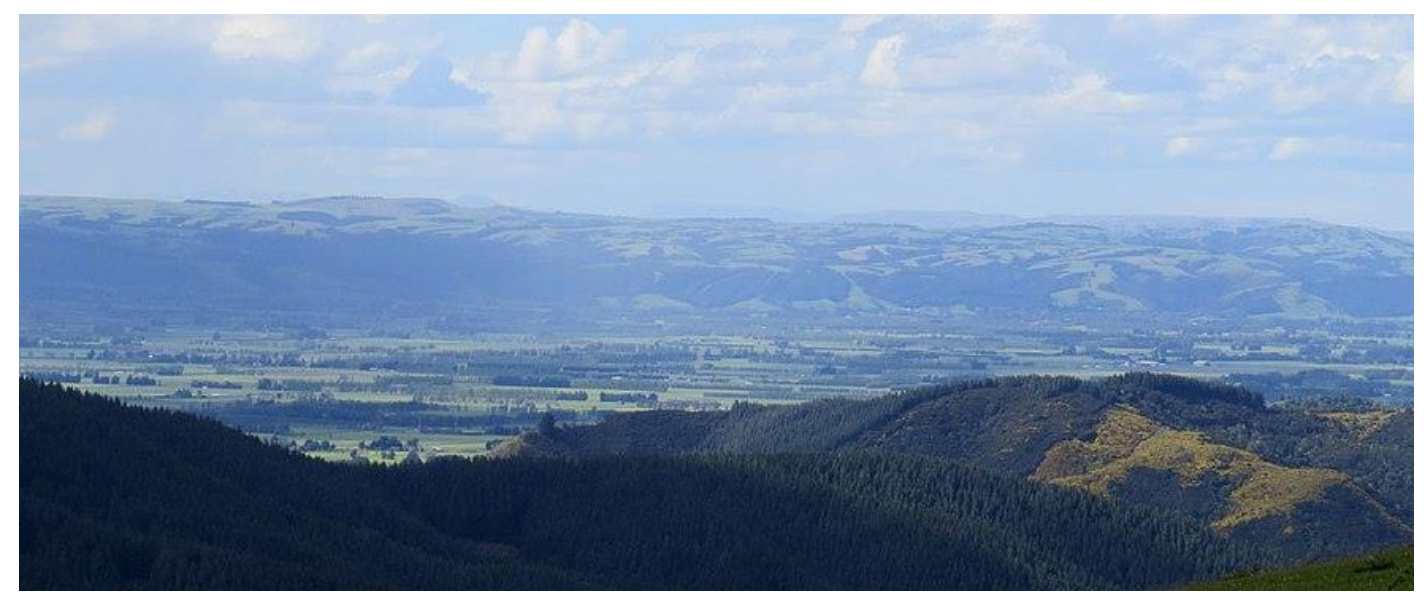

Figure 5. Taieri Plain from Southeast, 2014.

https://commons.wikimedia.org/wiki/File:Taieri_Plain_from_southeast.jpg. 
This photograph [fig. 5] is taken from the southern coastal hills. The flatness of the plain amidst the hills gives a sharp quality to the light and lines - quite different to the views from Dunedin out to sea, the rolling hills of the Peninsula or indeed of McCahon's beloved North Otago. Driving towards it, the Taieri gradually rolls out until a clear view of the entire plain is revealed. It is of modest size relative to other rural districts, covering an area of approximately 300 square kilometres. ${ }^{13}$ The fertility of the plain is reflected in its dense occupation, as marked out by the rows of trees and hedges in the photograph. In the 1930s it would have comprised several hundred farms. ${ }^{14}$ Today it is well-connected to Dunedin, but even in my childhood it was quite separate to the city, organized around Mosgiel - the "Pearl of the Plain" - and numerous small settlements. In their centennial history, published in 1947, Margaret Shaw and Edgar Farrant begin by referring to the Taieri as a patchwork, comprising 17 settlements, each of which was a "distinct social unit." 15 Such was the extent of human habitation and intensive farming that McCahon was un-seeing when he looked across the landscape.

As Paton notes in his section on South Island valleys, local people living and working in a place have a different relationship to the land to that of a "visitor or admirer." add social class to the distinction between local and visitor, between knowledge and novelty. In my upbringing in Mosgiel in the 1970s and 1980s I was not afforded a view across the hills where the underlying structure of the land and all its glory might become apparent. As I think now about his vision, I sense the middle-class McCahon looking over my head, over my experience, his mind filled with culture and ideas and art. Mosgiel was a thoroughly workingclass town, the large high school populated by about half farm kids and half town kids. While my upbringing was semi-rural, I was a "townie." I did, however, have many friends from farming families and frequently visited them, making vivid memories of milking cows on freezing afternoons, feeding out silage and racing around on quad bikes on long straight dirt tracks. These were good memories; but the overwhelming sense of being on the Taieri, be it farm or town, was uninspiring: a flat grid of streets and paddocks and fences, and straight-laced people. Basic people living honest lives, no doubt, but guided by conservative values that I felt increasingly at odds with.

My experiences growing up in this predominantly conservative community relate to my unease upon learning that McCahon's epiphany was connected to the Taieri. With all due respect to this community and to the undoubted exceptions to my generalisation, I think most would agree that this was the kind of place where McCahon's work was more likely to be derided than appreciated. ${ }^{17}$ Unlike Hokianga, or the Otago Peninsula, the Taieri Plain is not a place that has attracted artists or "alternatives." It is simply too flat, too exposed, too cultivated. There are no remote corners tucked away, no bush to retreat into, no dappled light. There are two counterpoints to this geographical monotony. First, Maungatua, a powerful presence for anyone who has lived on the Taieri, exuding both a forbidding and a protective aura. Referred to locally as "the Mung-ga-tuas" (hard "g"), the Māori name is actually Maunga-atua, meaning mountain of the Gods. This is fitting. I often stayed weekends with a friend on her family's dairy farm. I will never forget the feeling as we trudged towards the house in muddy gumboots and bush-shirts late on a winter's afternoon, the sun dropping quickly behind Maunga-atua, and the mountain just being - silent but terribly alive, seeing us safely inside, leaving it to look after the night. The second feature that broke the monotony of the plain was further along the chain of hills that provided McCahon's perspective: Saddle Hill, a charming and relatively benign presence. For local Māori, however, it was not so benign, but rather the remains of a taniwha named Matamata. ${ }^{18}$ 
These lived aspects of the geography, before and after his time, were not part of McCahon's purview as he drove over the coastal hills. His was a surveyor's perspective: he shared an actual vantage point with Otago's first official surveyor, and, more generally, a desire for an elevated view, to see over and above the plain to other high points in the landscape. ${ }^{19}$ While his representational paintings of this era show that he was not yet intent on sweeping away surface details, his eye was starting to appreciate the underlying structure of the land. ${ }^{20}$ Charles Cotton's 1922 Geomorphology of New Zealand is a well-known early influence in this regard, with McCahon coming across the book in the Dunedin Public Library around this time. ${ }^{21}$ The 1922 edition is still held in the McNab Room, a reference-only New Zealand collection, where it has always been. ${ }^{22}$ Unable to take it out of the library, here was a forerunner to McCahon's later insistence on the importance of memory in his landscapes, which he often painted at a distance, in time and space. We might add Cotton's sketches to the internal gathering of fragments - including the light over the Taieri that day-that continued to find expression as they melded with new places and new influences in the decades to come. It was in 1942 that McCahon came to own a copy of Cotton's book, receiving the new edition as a wedding gift. Perhaps soon after that he sketched the Taieri-or the gift may have inspired him to clamber up Flagstaff and render the plain.

\section{Sketching (1942)}

It was from a northern lookout, and a more experienced phase of life, that McCahon made his only known painting of the Taieri Plain. In the six years since his vision, he had spent three years at the Dunedin School of Art, followed by a period in the early 1940s in which he was trying to "find himself" as an artist. This was a time of itinerancy, of immersion in rural and working-class life, away from home and family. Summers were spent working on fruit and tobacco farms from Central Otago to the top of the South Island, and he spent several months working in a factory in Wellington. He continued to paint. By the end of May 1942, he was back in Dunedin, and it was not an easy time. He found jobs in pottery and paint-making factories, which he "hated" but was forced to do in order to earn some money. And, as Peter Simpson details, he was at odds with his future in-laws, frustrated by their middle-class expectation that he save a decent amount before marrying Anne, whom he had met whilst at art school. ${ }^{23}$ McCahon's easy middle-class existence of the 1930s had to some degree eroded, then, with his broader experience of different social settings and apparent embitterment with the constraints placed on his artistic endeavours by the pressure to earn a living by other means.

Interestingly, the Hambletts had previously lived in Mosgiel, with Anne spending the first seven years of her life there. It seems likely, then, that McCahon was familiar with the town, and the Taieri, and its people. There is no record of this, but there is a record that he had developed a dislike for Dunedin. In a letter to his sister in August, he wrote that "as I have said before and still say and know to be true, Dunedin is a dead city." ${ }^{24} \mathrm{He}$ was no doubt itching to return to the upper South Island, where most of his painting that year occurred. Only two works dated 1942 were painted in Dunedin. Both were oil on board, and both can be read as reflecting his feelings in those winter months. The first, a small work, was fittingly titled Dark trees, Dunedin. ${ }^{25}$ The second was his painting of the Taieri.

Sketch for landscape from Flagstaff [fig. 1] is a little-known work that, to my knowledge, has only been exhibited twice: at Dowse Art Museum in Lower Hutt, in 1986 Colin McCahon: A Celebration; and currently at Dunedin Public Art Gallery as part of $A$ Land of Granite: McCahon and Otago. ${ }^{26}$ Its northern perspective sees the coastal hills depicted on the left, Maunga-atua on the right, and the southern hills beyond Lake Waihola at the rear. The composition presents a striking contrast to the way the Taieri has been represented by artists 
wanting to highlight what is locally understood as its finest feature - the flat farmland at its centre. McCahon's work appears instead to de-emphasise the plain: minimising its size in relation to the surrounding hills, its flatness, the crispness of light it engenders, and the sharpness of its lines. Instead, the hills circle ominously, closing in any sense of open air, and the prized plain appears as a lumpy valley. The majestic Maunga-atua is cut off to the side, with the composition subtly oriented towards the coast. The colours are muted and dark, enhancing the feeling of depth and enclosure, but also carrying a pervasive sense of humanity and warmth.

The contrast between McCahon's sketch of the plain and typical renditions is made clear by comparison with the best-known Taieri landscape: George O'Brien's The Taieri Plains (1867) [fig. 6]. Drawn from a closer northern perspective, at Halfway Bush, it is in most respects a counterpoint to McCahon's image. The plain gleams: it is bathed in light, beautifully flat, pristine. With no signs of human occupation, but plenty of human inscription-roads and sections, paddocks of alternating colour indicating crops-it sets an inviting scene of picturesque, productive land laid out for the aspiring colonist. The sky carries no weight, all is open and airy. The forbidding Maunga-atua recedes into the background, and the interior beyond it beckons too. It is a classic colonist projection in this "boosterism," but O'Brien is regarded as one of a cohort of artists bringing a fresh approach to the distinctive New Zealand landscapes they painted. ${ }^{27}$ Erik Olssen notes that O'Brien's works would have been among those McCahon viewed at the Early Settlers Museum. ${ }^{28}$

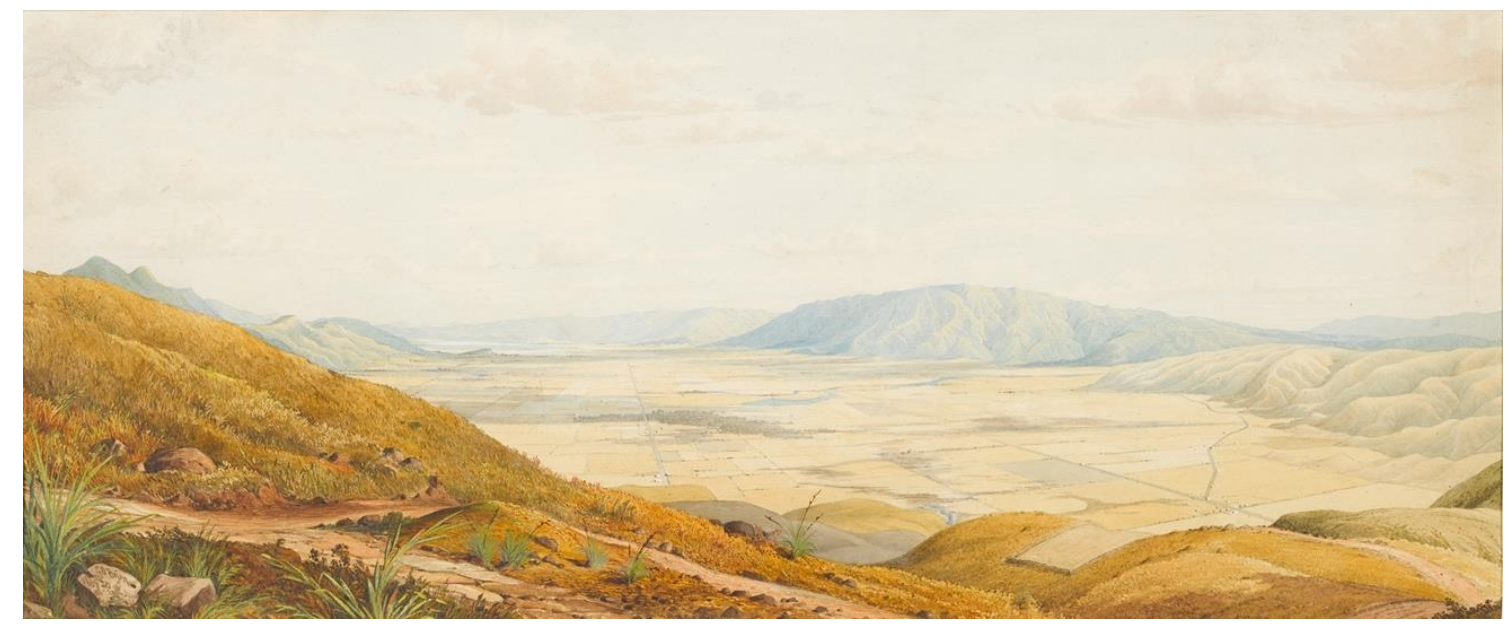

Figure 6. George O'Brien, 1821-1888, The Taieri Plains, 1867. Watercolour and opaque white on paper, $292 \times 704 \mathrm{~mm}$. Hocken Collections, Uare Taoka o Hākena, University of Otago, 7,475,

Dr T. M. Hocken's Collection.

O'Brien's depiction of an apparently tamed landscape was, however, largely aspirational, and thus as much of a product of "unseeing" as McCahon's work. In 1867, most of the Taieri Plain, particularly the southern end (to the rear of the images) was swamp. Perhaps this explains why this northern perspective, which relegates the swampland to the distance, was also the view that gained the first recorded positive description of the potential for the plain as a farming district, by Edward Tuckett in 1844. The British gaze had moved gradually moved inward from the coast in a kind of historic leap frog: Cook glimpsed (and named) Saddle Hill from the coast in 1769; in 1843 Edward Shortland was the first to document what lay beyond it, describing the Taieri Plain and looking across to the looming Maunga-atua; and four years later, Charles 
Kettle, official surveyor of the Otakou (Otago) Block, ascended Maunga-atua and viewed Central Otago, which he identified as having massive potential for pastoralism. ${ }^{29}$ His prediction for this extensive hinterland was more straightforward than the diverse opinions about the feasibility of the Taieri as an agricultural district. We can understand these doubts by descending into the plain and traversing the ground between McCahon's two vantage points.

Edward Shortland visited the Taieri in September 1843 in his role as sub-protector of the Aborigines. ${ }^{30}$ His account, the first documented description of the Taieri, was not positive. He approached the Taieri from the coastal route via Taieri Mouth, but rather than climbing over the coastal hills and taking in the full vista, he was taken to the plain by boat on the Taieri River as it winds through the gorge - a serene route between the hills. Here he was reliant on his Māori guides, who were fetched from the kaik (village) on the other side of the gorge. They escorted Shortland into the eastern part of the Taieri Plain by river, and then he and his party left their Māori guides and walked back to Dunedin over the hills. Shortland was not impressed, describing even the dry ground as unfit for cultivation and noting, as others would, the lack of timber. Almost a year later, Frederick Tuckett, surveyor for the New Zealand Company, wrote the first account from the elevated northern perspective, describing the moment the plain came into view as a "very prepossessing sight." 31 Another in his party, Dr. Monro, later published a vivid account in the Nelson Examiner:

We looked down upon a plain stretching away to the southward for at least twenty miles, with an average breadth of five or six, bounded on all sides by naked hills of rounded outline. This plain we learnt from the natives, was called the Tairii. Its general colour was a brownish yellow, broken only by the black hue of one or two patches of wood, and by the glitter of water, which seemed in some places to form lagoons, in others to wind about with many sinuosities. ${ }^{32}$

Aside from the "glitter of water," Monro's description accords quite closely with McCahon's much later painting. Monro's and Tuckett's accounts both move quickly from noting the expansive view to describing their descent into this scene of "brownish yellow" and dark patches. "As we approached nearer," Tuckett recalled, "it was apparent that much of it was subject to constant irrigation." Monro was at first enthusiastic about the fertile soil they came upon, but found it was of "limited extent" and as they landed in the valley they soon found themselves in "marshes," "wading up to our knees . . crossing many grass-tree swamps, in which an injudicious step often plunged us to a much greater depth." It was "impossible to walk far or long," and after covering only about eight miles they stopped and camped in the foothills on the eastern side of the plain. The next day they encountered "a large canal looking stream of dark peaty water, appearing to cross over from the western side of the valley," and Monro summed up their walk as a "most fatiguing one"- either wading through "fern and coarse grass over our heads" on a narrow strip of land beside the river, or dealing with the swamp. ${ }^{33}$

On the third day they reached the lower Taieri River, at the far southern end of the plain, and upon finding they could not cross it and continue south as planned, they instead climbed the coastal hills-McCahon's 1936 vantage point. This view immediately convinced Monro that the Taieri Plain was once a lake. His description of the processes of its geological formation that were so clearly laid out in front of him are a resounding echo of McCahon's vision of its structural elements. But the basin that Monro looked over was very different to the patchwork of farms in McCahon's time. Monro's summation was that the upper third of the plain was available, "but the lower two thirds can hardly be called terra firma, being in fact, an immense grass-tree swamp, through which canals of black sluggish water wind in various directions, 
and interspersed with stagnant lagoons." Worse still, he feared "that this swamp is not susceptible of being drained, for its level is not above that of the sea." ${ }^{34}$ And so it was that two years later, when Charles Kettle drew up the official survey map of Otago [fig. 6], he left the large swamp area at the southern end of the plain blank. It was not intended for settlement.

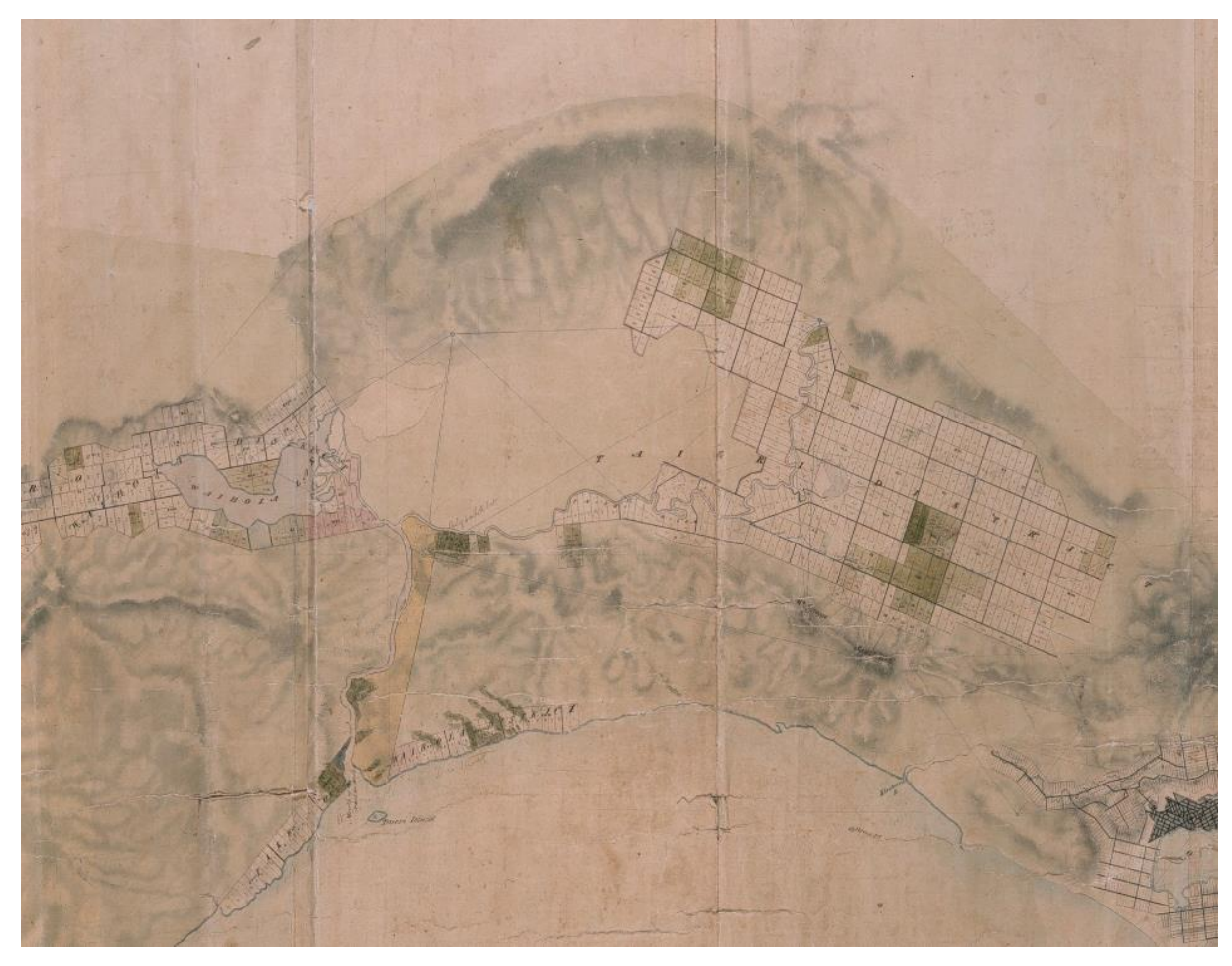

Figure 7. Detail, Index Map of the Otakou Settlement Middle Island New Zealand, 1846-47, C. H. Kettle. Archives New Zealand, Dunedin Office, R698465. Coastal hills in the foreground and Taieri Plain at centre and right. The large blank area in the centre was swamp and was not initially surveyed, but would become the prime farming land - this is the area that McCahon looked over from the hills in 1936. Flagstaff is at the right.

What happened in the century between the descriptions and depictions of colonial surveyors and artists and McCahon's time can be read as a standard narrative of pioneering and "improvement." The mostly Scots migrant families, who began to arrive in numbers from the late 1840s, rapidly applied modern farming methods that they were already skilled in, including large-scale drainage. By 1900 the entire plain, including the initially unsurveyed southern end, had been gridded, titled and sold; and the land was gradually moulded into a local pattern of freehold and leasehold ownership by the idealised small family farm that persisted in New Zealand more than any other settler colony. ${ }^{35} \mathrm{~W}$. T. Neill's beautifully drawn maps of the early 1900s detail the density of this occupation. The detail below [fig. 8], of a portion of the southern end of the plain, shows how farms were established around patches of persistent wetlands (indicated by the "v" pattern) and winding canals that echo Monro's "many sinuosities" description. The map makes a strong visual statement about the contest between inconvenient waterflows and neatly drawn pencil lines - which so effortlessly dominate on paper, and were made tangible in straight fences and roads, but which were ultimately at the mercy of water. 


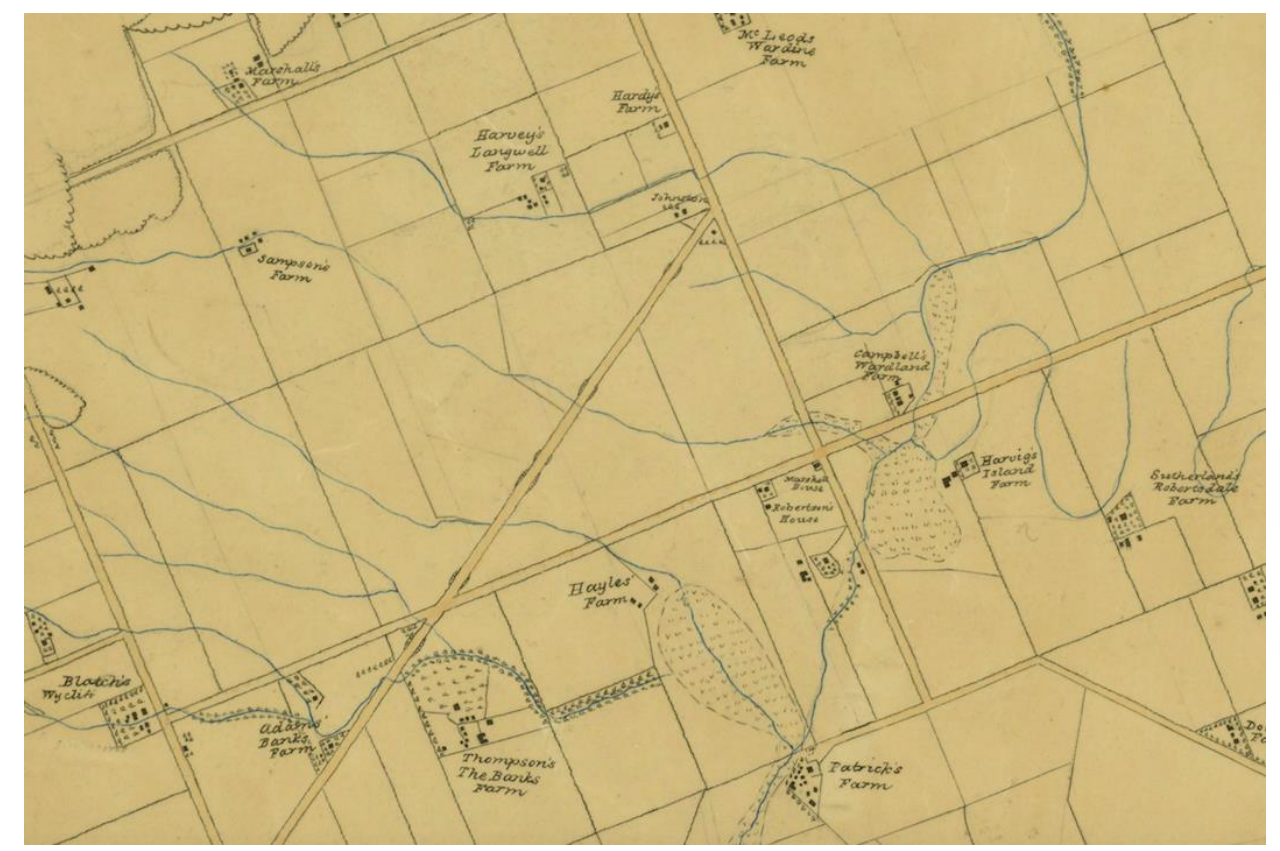

Figure 8. Detail, W T Neill's Military Topographical Maps, 1901-c.1904, Sheet No. 21 Parts Maungatua and West Taieri Districts. Archives New Zealand, Dunedin Office, R23188986.

A more nuanced story of the Taieri, therefore, would focus less on land and more on water and the necessity to work around it. ${ }^{36}$ Water is the natural feature that has most affected the development of Taieri farming - in practice, identity and community dynamics. For it was not only the prevalence of swamps, canals and lakes that challenged efforts to make this waterlogged basin productive and habitable, but also that it was a flood plain for both the Taieri and Waipori Rivers. In February 1868, soon after O'Brien painted the Taieri, a devastating flood submerged the plain and wiped out the town of Outram, the main settlement at that time. Outram was shifted to a new site, and farmers formed boards and undertook a series of labourintensive measures to alter the contours of the land, and the flow of water, in order to make long-term farming and habitation viable. ${ }^{37}$ The formation of the Taieri River Trust and the substantial works carried out in the 1920s - within McCahon's time-protected the southwest area, once the most waterlogged but later recognised as the best farmland. In the process, seemingly unsurmountable conflicts have developed between families on the protected western side and those on the east whose properties were negatively affected by the flood scheme. Whether one farms east or west of the Taieri River determines much about one's place in the local community.

This brief foray into the surveying and social history of the Taieri allows us to more fully appreciate what is seen and unseen in McCahon's painting; to better grasp what is concealed and revealed. As noted already, the composition de-emphasises the plain, and there are further erasures and inclusions we can now address. Broadly, there is no evidence of human intervention on the plain: no fences or paddocks, no roads or railways (though the trees in the foreground evidence planting of exotic trees on the hills). Nor is there any sign of human occupation in the form of houses and buildings. This entails the erasure of not only intensive farming, but also the entire township of Mosgiel, which is visible from Flagstaff, and at the time was home to over 2,000 residents. ${ }^{38}$ It is located at - and perhaps indicated by - the (symbolic?) dark patch at the foot of the coastal hills. For those with knowledge of the district's early history, this is reminiscent of "The Bush," as the site of Mosgiel was originally known; 
it stood out as an area of substantial forestation in this landscape otherwise noted for its lack of timber. ${ }^{39}$

This dark patch and others in the painting can also be read as infusing the work with the waterlogged nature of the plain. The large dark area on the right maps onto the part of West Taieri originally known as "The Swamp," and the concentrated circle of dark at the rear is the site of Lake Waipori. In these inscriptions and the other features described above - the tawny colours, the sense of enclosure-we could see in Sketch for landscape from Flagstaff an early example of McCahon's ability to "expand timeframes," relating the contours of the land to the human experience of it and thereby gesturing towards its pre-drainage qualities. ${ }^{40}$ As to the Taieri River, so prominent in its physical and social history, it seems likely that the arc in the lower right corner depicts it. The river may also be indicated by the boldest and most notable feature in the image: what appears as a wide channel down the centre. This is notable because it does not reflect any lines on the external landscape, yet calls to mind an essential but easily overlooked characteristic of the Taieri: as a "moving through" place. I will expand on this further suggestion of the prophetic nature of McCahon's work in the next section.

McCahon's 1942 sketch of the Taieri was a fitting bookend to colonial era descriptions and depictions. While early British surveyors and observers looked beyond what was in front of them to imagine "new" land being created out of swamp, and optimistically painted it as such, a century later McCahon saw through the drastic alterations to landscape (and waterscape) and captured something of the essence of what the place was before, and what it may become again. In this seeing and unseeing of a place, the image can also be read as a projection of McCahon's situation in Otago in the early 'forties: hemmed in, dark, brooding. As centenary publications for Otago and the Taieri were being shaped into narratives of "arrival," McCahon was ready to depart. Even the author of Otago's centennial history would have understood his move: the final section of A. H. McLintock's impressive monograph paints a dull picture of the 1940s arts and culture scene in the province. ${ }^{41}$

\section{Re-Imagining (1966, 2020)}

When McCahon was commissioned to write an essay about his "Beginnings" for Landfall in 1966, he was settled in Titirangi, and in the midst of a productive phase of his career. Since leaving Dunedin he had lived in Nelson and Christchurch, and spent formative time in Melbourne before settling in the north, from where he continued to regularly travel. He had established his reputation as a modernist painter and was on the cusp of giving up his position at Auckland Art Gallery to paint fulltime. It was an appropriate point at which to reflect on the origins of his inspiration, particularly related to the land. The memory work required was likely aided by having begun his "North Otago" series the same year, itself drawing on those early fragments of memory, including that of Charles Cotton's work-presumably the source of his comment about the processes of "normal erosion" in the catalogue for that work. ${ }^{42}$ In the North Otago series we see the culmination of decades of refinement in works of evocative abstraction, which he had also applied to the Canterbury landscape in the 1950s.

When I first undertook to write this article, I planned to explore the relationship of McCahon to the rural people who were erased from his increasingly abstract landscapes. This was made difficult by the shifting meanings of "rural." In McCahon's time, most New Zealanders lived a relatively rural life, and so to claim that he was somehow detached from those communities was not a strong starting point. But I do want to return here to my earlier point about the reception of McCahon's work in places like the Taieri. I am inclined to believe that farming people have not generally been drawn to his work, preferring more representational, idealised 
depictions of the landscapes which are also their livelihoods, and which celebrate the fruits of their family's labour. Certainly, my experience of living on the Taieri in the 1970s-80s would suggest that is the case. But what I want to offer here, as a bridge across such understandings of the division between rural communities and their urban counterparts, is that if McCahon is speaking directly to anyone about the raw power of the land - its haunting ability both to isolate and to engender a strong sense of belonging - he is speaking to rural people, across cultures, who most viscerally reckon with it, at all hours of the day and night, in a way that their lives depend on. Given the severe economic and environmental challenges farmers on the Taieri have faced, I am sure that any local could relate to the sense of enclosure and the swampy origins depicted in Sketch for landscape from Flagstaff.

As to the details that were included in the work, one can consider McCahon's subsequent use of panels from the 1958 Northland series onwards. As Peter Simpson's essay in this issue states, McCahon was a great believer in narrative, often using grids and panels to tell a story. Looking again at the Taieri image, it is unusual for the amount of story it containsoverlapping histories and uses, routes and directions, experiences and feelings, and a number of natural features, including the arc that likely depicts the Taieri River, which bears a strong resemblance to the waterfall paintings of the 1960s. In a later treatment, one could imagine the effect of separating these features into grids or panels, arranging them so as to enable the layered storytelling that McCahon's work became so adept at doing.

One final aspect that might be retrospectively considered in relation to Sketch for landscape from Flagstaff is McCahon's interest in te ao Māori. As Paton notes, while his early works did not contain overt references to Māori, they did exhibit an instinctive understanding of (or prefigured an interest in) Māori beliefs and connections to land. ${ }^{43}$ Yet McCahon's statement in "Beginnings" about seeing an order and beauty in a place that was yet to be "invented" has been subject to critique for its apparent alignment with colonial ideologies of improvement of what were perceived as empty, ahistorical spaces. ${ }^{44}$ As Francis Pound and others have asserted, these places had of course been significant to Indigenous culture, as well as lived in by Indigenous people, for many hundreds of years. McCahon's statement has been attributed in part to his southern origins, and the notion that Pākehā in the South Island have been less engaged with te ao Māori due to the lower population and visibility of Indigenous communities there, compared to North Island Pākehā. The problem with this assertion is that it can work to reinforce the erasure of southern iwi. Here, then, is an opportunity to - albeit briefly - put local iwi back into this picture, and to consider the effect of Anglo-naming in constraining our ability to imagine its pre-colonial occupation.

One of the early findings of my study of family farms in Taieri and Hokianga was the prevalence of Anglo-naming in the south compared to the north, where Māori names have persisted for the great majority of settlements and roads, rivers and mountains. While this was expected, the extent to which the Taieri was populated with Anglo-names was notable. W. T. Neill's maps, cited in the previous section, named not only the occupant families, but also the farm. Instances of this can be seen in figure 8, with Sutherland's "Robertsdale" farm, Campbell's "Wardland" farm, and so on. This detail proved useful for tracing ownership patterns, but added another layer to the colonial project of erasure of existing names. ${ }^{45}$ Contrastingly in Hokianga, even the government "special settlement" schemes of the late nineteenth century, designed to displace local hapū and entice British farming families into the district, had Māori names. ${ }^{46}$ Having learnt of the widespread farm-naming practice on the Taieri, I enquired about any local equivalent when conducting my fieldwork in Hokianga. In a rather poetic response, one interviewee recalled an Anglo-name on a sign at his farm gate some 
decades ago, but it was old and faded. He could not remember the name, and the sign was long gone. Meanwhile on the Taieri, these farm names persist and are often proudly displayed on large signs at the gate.

The consequence of these naming practices is only recently being brought squarely into the public realm. How might McCahon have responded differently to the Otago landscape if he knew Flagstaff as Te Whānaupaki, if he knew the stories of Moturata Island (at Taieri Mouth) or the taniwha Matamata whose remains became known as Saddle Hill? I could ask the same questions of myself. Growing up on the Taieri in the 1970s and 1980s, I had no idea that it had ever been a Māori place, and I do not recall even being aware that Taieri was a Māori word. While there was some retention of original names - Ōtokia, and Lakes Waipori and Waiholathese are greatly outnumbered by British names. It was not until the publication of Angela Wanhalla's appropriately titled monograph In/visible Sight, that I learnt about local Kāi Tahu families of mixed-race descent, and indeed that there had ever been a Māori Reserve on the Taieri. ${ }^{47}$ The scholarly consensus regarding the pre-colonial occupation of the Taieri is that while the plain was never a place of substantial settlement, it was always an important site for mahinga kai (seasonal food gathering) and for moving between coastal settlements and those in the interior, beyond Maunga-atua. ${ }^{48}$ From its earliest habitation, then, this was a "moving through" place.

In pre-colonial times, this movement occurred via the river. When Monro described walking through the swamp in 1844, he noted that the party's Māori guides seemed to struggle with the terrain as much as their visitors. He questioned them about this, given their experience of the place. His guides simply pointed to the river, and said "there was their highway." 49 Looking at Sketch for landscape from Flagstaff, it clearly has the capacity to tell this story, with the river/road/channel imagery suggested by the bold lines mapping onto the Māori route across the Taieri, and what would become the Pākehā route too. While the river was initially the primary means of transporting people and food, roads along the same orientation were soon built. The consolidation of these roads and then railways owed much to the influx of people and wealth into Otago in the goldrushes of the early 1860s, which again saw the plain function as a throughway from Dunedin's port direct to Central Otago. Even today, most people experience the Taieri by driving through it on their way to Dunedin from its international airport, located at the southern end of the plain. The direction of the runway eerily mirrors McCahon's channel.

The persistence of this "moving through" characteristic is of course a small counterpoint to the impact of gridded survey lines, which have inexorably straightened the way one moves across the plain. It is impossible now to reconstruct the sense of meandering that the sinuosity of the river must have engendered, or indeed what it felt and sounded like when it was a "swamp." But at Sinclair Wetlands, located at the southern edge of the plain, gradual reversion to the tawny brown of McCahon's painting has been underway for several decades [fig. 9]. It is an initiative that brings together the threads explored in this article. The land was purchased by Horrie Sinclair as a farm in the 1960s. In an effort to attract native birdlife back to the place, Horrie began the long but rewarding process of allowing the land and water to find balance, and thus recreate the habitat for local species. Horrie was far ahead of his time with this project, but gradually he began to draw positive attention for it. In the 1980s the land was gifted to a trust, and then returned to Ngāi Tahu in 1998 as part of their treaty settlement. ${ }^{50}$ The current manager, Glen Riley, has greatly extended Horrie's work and is also forging ahead with his own re-imagining of what this place once was and could be-a pathway shaped by environmental and cultural ethics as well as the practical matters of maintaining a wetland 
surrounded by farms. Glen is committed to restoring a place of mahinga kai, and a place where the story of the Kâti Mamoe rangatira Tukiauau taking refuge on the Whakarapuka (Ram Island) features in all of his tours. ${ }^{51}$

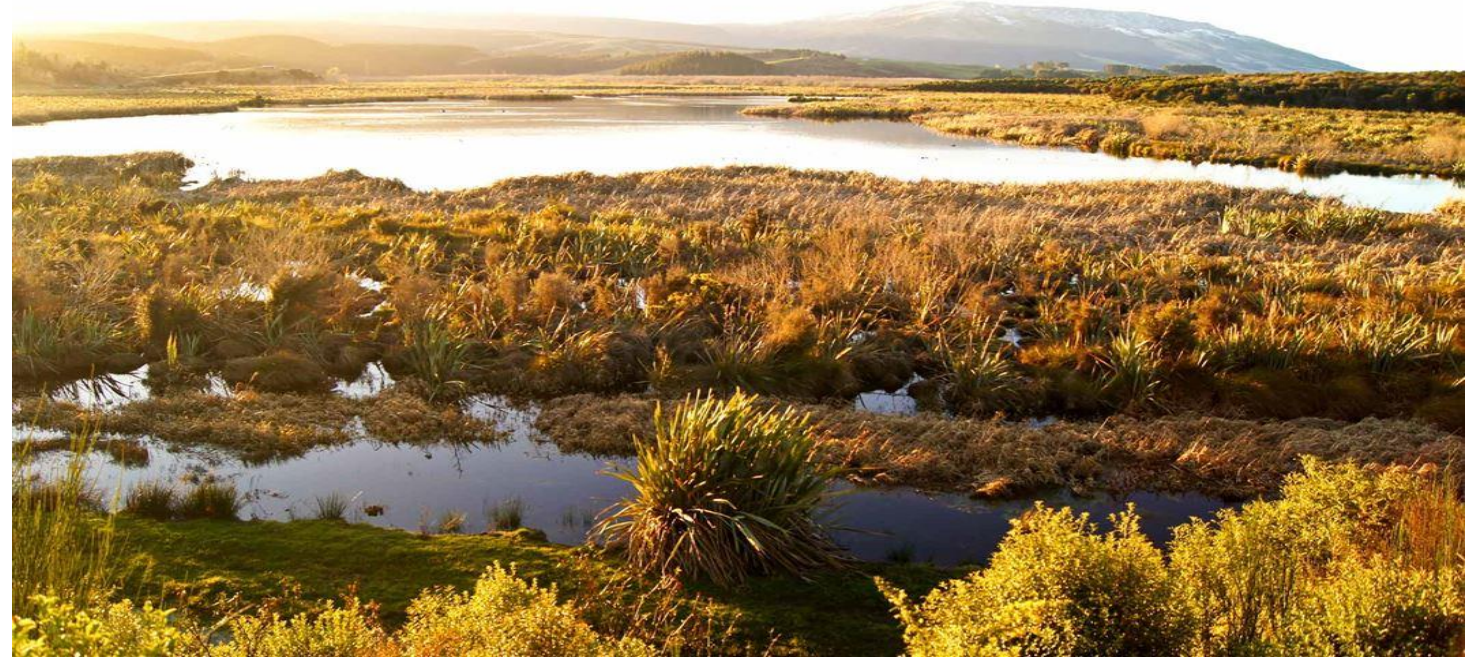

Figure 9. Sinclair Wetlands (photograph from Department of Conservation website).

\section{Conclusion/Postscript}

In 2017, as I prepared the proposal for my study of land and inheritance, I took a tour of the Taieri with my father, Don McCabe. A diesel mechanic by trade, Dad knows the district intimately, having serviced farm machinery for local families for almost 40 years. Looking back now, I realize that our tour mirrored McCahon's perspectives. We began from the northern view, at the Three Mile Hill lookout. Dad pointed out the various settlements (Henley, Berwick, Outram) which I only ever knew from ground level - I had never taken this high view and situated the places of my childhood. The winding road took us down, away from the view, depositing us onto the northern plain, where the long straight roads reduced the place to its old familiar feeling. Chatting as we drove along on its western edge in the shadow of the Maungaatua, there was little to see aside from the odd run-down house visible from the road. Reaching the southern end of the plain, we followed the main road across to Henley, after which Dad directed me to a right turn up a narrow steep road, a slightly scary manoeuvre against the flow of motorway traffic, that took us up to our final vantage point - the site of McCahon's epiphany, atop the eastern hills for that rare, peaceful view of a place that has seen its share of history.

\footnotetext{
${ }^{1}$ W. A. Taylor, Lore and History of the South Island Maori (Christchurch, NZ: Bascands, 1952), 138. See also the Ngāi Tahu cultural atlas of South Island Māori place names: https://www.kahurumanu.co.nz/atlas.

${ }^{2}$ McCahon did spend further time in Dunedin in the mid- to late 1940s, staying with relatives and painting a number of important works. See Peter Simpson, Colin McCahon: There Is Only One Direction. Vol. 1 1919-1959 (Auckland: Auckland University Press, 2019), 65-67.

${ }^{3}$ In addition to studies of Otago Peninsula, early paintings by McCahon depicted urban scenes including the Dunedin Botanic Garden, Tahuna Park and Leith Valley. See http://www.mccahon.co.nz/browse/date.
} 
${ }^{4}$ Simpson, There Is Only One Direction, 68.

${ }^{5}$ In 2017, I was awarded a Royal Society of New Zealand Marsden Fast-start grant for the project

"Splitting Up the Farm? A Cross-Cultural History of Land and Inheritance in Aotearoa, 1870-1970."

This three-year grant ended in February 2020 and I am currently writing a monograph from its findings for Auckland University Press entitled Land Chains: Inheritance, Culture and the Family

Farm.

${ }^{6}$ Justin Paton, McCahon Country (New Zealand: Penguin, 2019). Zoe Alderton also takes an immersive approach to particular locales in The Spirit of Colin McCahon (Newcastle on Tyne:

Cambridge Scholars Publishing, 2015). There are many other examples of comparing actual places to McCahon's painting. In discussing Takaka Day and Night (1948), for example, Richard Morris states that "anyone familiar with the Takaka region of New Zealand will notice [the painting] is more general than it is specific" ("The Interior Landscape: Metaphors for Faith and Belief in the Religious Paintings of Colin McCahon," Colloquium: The Australia and New Zealand Theological Review 43, no.1 [2011]: 2). The current exhibit at Dunedin Public Art Gallery, "A Land of Granite: McCahon and Otago," has a catalogue map that encourages the audience to visit local sites relevant to the artist and his work: https://dunedin.art.museum/assets/EX-Land-of-Granite-McCahon-and-Otago/A4-Land-ofGranite-Guide.pdf.

${ }^{7}$ Colin McCahon, "Beginnings," Landfall 20, no.4 (1966): 363-64.

${ }^{8}$ In his detailed account of the Otago landscape, historian A. H. McLintock describes a "general uniformity that springs from its surprising diversity" (The History of Otago: The Origins and Growth of a Wakefield Settlement [Dunedin: Otago Centennial Historical Publications, 1949], 14).

${ }^{9}$ Simpson, There is Only One Direction, 38.

${ }^{10}$ McCahon, "Beginnings," 362.

${ }^{11}$ Erik Olssen, A History of Otago (Dunedin: John McIndoe, 1984), 232.

${ }^{12}$ See Peter Simpson, “Candles in a Dark Room: James K. Baxter and Colin McCahon," Journal of New Zealand Literature no.13 (1995): 157-88.

${ }^{13}$ By way of contrast, the Canterbury Plain, the largest in New Zealand, is 16,800 square kilometres.

${ }^{14}$ Margaret Shaw and Edgar Farrant, The Taieri Plain: Tales of Years that Are Gone (Dunedin: Otago Centennial Historical Publications, 1949), 2.

${ }^{15}$ Shaw and Farrant, The Taieri Plain, preface (not paginated).

${ }^{16}$ Paton, McCahon Country, 37.

${ }^{17}$ Simpson, There Is Only One Direction, 21.

${ }^{18}$ There are different versions of the creation story of Saddle Hill in local Kāi Tahu tradition. See Jonathan West, "An Environmental History of the Otago Peninsula: Dialectics of Ecological and Cultural Change from First Settlement to 1900" (PhD dissertation, University of Otago, 2009), 70-71 and f.n. 11. Kāi Tahu leader Tahu Potiki relates the Matamata narrative here:

https://www.youtube.com/watch?v=m1SxyJG8E4w.

${ }^{19}$ Charles Kettle's official survey in 1846-47 used several points along these hills in his triangulation method, with remarkably accurate results. George Davis, "Old Identities and New Iniquities: The Taieri Plain in Otago Province, 1770-1870" (MA dissertation, University of Otago, 1973), 84.

${ }^{20}$ Simpson, There Is Only One Direction, 48.

${ }^{21}$ Gordon H. Brown discusses Cotton's influence in depth, and suggests 1939 as the year McCahon first located it, in Towards a Promised Land: On the Life and Art of Colin McCahon (Auckland: Auckland University Press, 2010), 101-08.

${ }^{22}$ Thanks to Julian Smith at Dunedin Public Library for this little gem of a detail.

${ }^{23}$ Simpson, There Is Only One Direction, 57.

${ }^{24}$ Simpson, There Is Only One Direction, 57.

${ }^{25} \mathrm{http}: / /$ www.mccahon.co.nz/cm001292.

26 "A Land of Granite: McCahon and Otago" was developed by Dunedin Public Art Gallery and exhibited from 7 March to 18 October 2020.

${ }^{27}$ Erik Olssen likens O'Brien's work to that of William Hodgkins, in moving "beyond sentimental romanticism to portray the New World with freshness," in A History of Otago, 81 . He also received a favourable write-up in Art New Zealand 3 (December/January 1976-77) http://www.artnewzealand.com/Issues1to40/obrien.htm. 
${ }^{28}$ Olssen, A History of Otago, 232.

${ }^{29}$ McLintock, The History of Otago, 18.

${ }^{30}$ Shaw and Farrant, The Taieri Plain, 3.

${ }^{31}$ Shaw and Farrant, The Taieri Plain, 4.

${ }^{32}$ Shaw and Farrant, The Taieri Plain, 4.

${ }^{33}$ Shaw and Farrant, The Taieri Plain, 5.

${ }^{34}$ Shaw and Farrant, The Taieri Plain, 6. The western end of the Taieri Plain is indeed below sea level, and up to two metres below sea level near Momona-New Zealand's lowest point.

${ }^{35}$ For the persistent idealization of the small family farm in New Zealand, see Tom Brooking,

"“Yeotopia' Found ... But? The Yeoman Ideal that Underpinned New Zealand Agricultural Practice into the Early Twenty-First Century, with American and Australian Comparisons," Agricultural History 93, no.1 (2019): 68-101.

${ }^{36}$ Angela Wanhalla does exactly this for Kāi Tahu families in the period up to 1920 in "Living on the River's Edge in Taieri Native Reserve," in Indigenous Communities and Settler Colonialism: Land Holding, Loss and Survival in an Interconnected World, ed. Zoe Laidlaw and Alan Lester (London: Palgrave, 2015), 138-57.

${ }^{37}$ Shaw and Farrant, The Taieri Plain, 67-76.

${ }^{38}$ https://www3.stats.govt.nz/New_Zealand_Official_Yearbooks/1940/NZOYB_\%201940.html.

${ }^{39}$ The contrast was vividly rendered in John Buchanan's monochrome wash "Taieri Bush and Saddle Hill," from his 1856 scrapbook, held at Alexander Turnbull Library and reproduced in Olssen, A History of Otago, 47.

${ }^{40}$ Paton, McCahon Country, 19.

${ }^{41}$ McLintock, The History of Otago, 787-89.

${ }^{42}$ Charles Cotton used the phrase in the title of his 1941 monograph: Landscape as Developed by the Processes of Normal Erosion (Cambridge: Cambridge University Press, 1941).

${ }^{43}$ Paton, McCahon Country, 16.

${ }^{44}$ Francis Pound, The Invention of New Zealand: Art and National Identity, 1930-1970 (Auckland: Auckland University Press, 2009), 55.

${ }^{45}$ Angela Wanhalla has made this point using the example of Owhiro in East Taieri, which was originally named by the British as Scrogg's Creek, after a surveyor; then Greytown, after Governor George Grey; and finally Allanton, after a prominent farming family ("Transgressing Boundaries: A History of the Mixed-Descent Families of Maitapapa, Taieri, 1830-1940” [PhD dissertation, University of Canterbury, 2004], 94).

${ }^{46}$ Special settlements in the Hokianga district in the late-nineteenth century included Waiotemarama, Waimamaku, Punakitere and Motukaraka.

${ }^{47}$ Angela Wanhalla, In/visible Sight: The Mixed-Descent Families of Southern New Zealand (Wellington: Bridget Williams Books, 2009). In this article I use "Kāi Tahu" in accordance with the southern dialect where the "ng" sound is replaced by a "k," except for official use and names that specify Ngāi Tahu.

${ }^{48}$ Harry C. Evision, Te Wai Pounamu: The Greenstone Island (Wellington: Aoraki Press, 1993), 178; Wanhalla, "Transgressing Boundaries," 97-100; Atholl Anderson, "Maori Settlement in the Interior of Southern New Zealand from the Early 18th to Late 19th Centuries A.D.," The Journal of the Polynesian Society 91, no.1 (March 1982): 53-80.

${ }^{49}$ Shaw and Farrant, The Taieri Plain, 5.

${ }^{50}$ The area is owned by Te Rūnanga o Ngāi Tahu and since 2011 has been managed by Te Nohoaka o Tukiauau Sinclair Wetlands Trust. For more information see https://www.tenohoaka.org.nz.

${ }^{51}$ Interview with Glen Riley, Sinclair Wetlands, 13 June 2019. 